\title{
ВЕРА И ЗНАНИЕ КАК КОМПОНЕНТЫ ИДЕОЛОГИИ
}

\section{О.И. Заздравнова, А.П. Заздравнов}

Особую роль в человеческом бытии играет необходимость не только заниматься актуальной деятельностью, но и придавать своему существованию смысл, формировать цели, а вместе с ними и будущее. Результатом и средством определяющих целей индивидуального и социального бытия является идеология, неотъемлемыми компонентами которой выступают вера и знание. При переводе социального идеала во внутренний мир человека, чего, собственно, и добивается любая идеология, формируются не просто чувство убежденности, но и установки веры. Исследование содержания идеологии в единстве веры и знания является целью данной статьи.

Появление веры относится к тому моменту, когда в социуме начинает укрепляться мысль о неслучайности появления человеческого рода, о назначении человека дать миру образец справедливости и тем самым обеспечить устойчивость и гармоничность в соотношении Бога, природы и человека. «Дело в том, - пишет П. Бергер, - что общество удерживается как единое целое не просто в силу практической необходимости и совместных интересов: его сплачивает вера, которая объясняет и оправдывает установленный социальный порядок» [1, с. 247].

Один из наиболее глубоких исследователей социального менталитета Х. Ортега-и-Гассет отмечает: «Верования - основа нашей жизни, это та почва, на которой жизнь осуществляется, они ставят нас перед тем, что есть сама реальность. Всякое поведение, включая интеллектуальное, зависит от того, какова система наших истинных верований. В верованиях мы «живем, в них движемся и являемся ими». А потому у нас нет обыкновения осознавать их, мы о них не думаем, они скрыто

Актуальні проблеми духовності 
обусловливают все, что мы делаем и думаем. Когда мы по-настоящему верим, у нас нет никакой «идеи», мы просто полагаемся на это, как на нечто само собой разумеющееся» [3, с. 467]. Именно вера становится сдерживающим фактором, препятствующим полному погружению человека в мир исключительно утилитарных приоритетов в процессе исторической эволюции.

В данной статье идеология предстает как система верований, отбирающая наличные знания для собственной легитимации, причем предпочтения отдаются знаниям, которые существуют в сращенности со средствами их практической реализации. $\mathrm{K}$ «чистым» теоретическим знаниям идеология равнодушна: ведь у них отсутствует имидж заземленности на актуальных проблемах социума. Заслуживает внимания мысль Б. Рассела: «Ясно, что знание представляет собой класс, подчиненный истинной вере: всякий пример знания есть пример истины веры, но не наоборот» [4, с. 170].

Анализ содержательной стороны идеологии приводит к выводу, что вера и знания в этом социокультурном феномене тесно взаимодействуют. Если традиционно считалось что основной функцией знания является постижение истины, то в идеологическом процессе наблюдается тенденция отвращения людей от «бесплодной истины», выработка иммунитета к абстрактному знанию во имя приобщения к знанию, максимально приближенному к социальным потребностям и идеалам. Массовое сознание не в состоянии осваивать идеологические концепции в «чистом» виде, нередко воспринимая их лишь на уровне веры. Напротив, идеология, дабы утвердиться в массовом сознании, вынуждена поступаться элементами научности, логической обоснованности и вновь использовать уже преодоленные мифологические образы, схемы и аналогии.

Наличие иллюзорного знания в идеологии, определенных ложных идеях, понимание ее как способа выражения социально-классовой позиции не снимает вопроса о целесообразности существования идеологии в эволюционирующем социуме. М. Вебер уже не отождествляет идеологию исключительно с ложным или иллюзорным сознанием, а вычленяет ее созидательные функции по отношению и к личности, и к обществу даже тогда, когда в ней явно преобладают элементы иллюзорности. К. Мангейм открывает в идеологии метод социального познания, рассматривая ее и как универсальную социальную теорию, призванную задавать генеральную ориентацию совокупной человеческой практики.

Поскольку идеология использует иллюзорное знание, постольку ее 
соотношение с такой формой общественного сознания, как религия, представляется правомерным. Ориентирующаяся на веру, а не на доказательное научное знание, религия выстраивает для себя трансцендентный мир. «Ведь главная цель всякой религии, - как отмечает А.И. Яковлев, - сознание, душа человека, его сознательное служение Богу» $[7$, c. 4]. Но этот мир сосуществует с миром реалий, который доступен или чувственному созерцанию, или рациональному осмыслению. Вера в трансцендентный мир ориентирует человеческую деятельность, индивид учитывает этот мир в своих поступках. Однако большая часть религиозных верований не касается ничего трансцендентного: содержание религии зачастую ограничивается миром социальной реальности, который воспринимается в его непосредственной данности. Но, тем не менее, усвоение верований и их широкое трансцендирование свидетельствует, что они соответствуют интересам и чаяниям отдельных индивидов и социальных групп. Коллективные верования, разделяемые различными социальными группами, тесно связаны с их интересами, ориентирующими их действия в социальной сфере независимо от того, входят они в религиозное сознание или существуют вне его. Они с необходимостью присутствуют в идеологии. Поэтому именно идеологическими установками наиболее четко определяется жизнь определенной исторической эпохи. Ими же на отдельных этапах человеческой истории задаются жесткие параметры мышления и поведения людей.

Ортодоксальный марксизм, постоянно уповающий на научность своих идеологических установок, в практике их внедрения широко использует аргументацию «от веры», а не от близкого знакомства с теоретическими положениями «Капитала» К. Маркса. «Во всем этом скрыта глубокая ирония, ибо трудно поверить, чтобы из миллионов людей, использовавших марксизм с этого дня, когда увидел свет «Капитал», более чем горстка приняла революционную веру под влиянием трудно-усвояемой прозы этих увесистых томов» [1, с. 250].

Согласно Н. Бердяеву (и даже некоторым апологетам марксизмаА. Грамши, П. Тольятти, Э. Блоху), марксистская идеология эксплуатирует «на потребу масс» не столько принципиально новые знания, которые были выявлены классиками в процессе скрупулезного исследования реалий буржуазного общества, сколько эсхатологические мотивы библейской мифологии. «Другими словами, марксизм нужно рассматривать в качестве особой светской версии классического библейского взгляда на историю; здесь и грехопадение, и ряд искупительных деяний в рамках человеческого сообщества, и великий кульминаци- 
онный пункт, призванный завершить период обыкновенной истории. Марксизм заменил первородный грех частной собственностью и «отчуждением», искупительную деятельность - революционным процессом, церковь - пролетариатом, а пришествие Христа - достижением полного коммунизма» [1, с. 251].

Итак, наличие черт мифологической и религиозной веры в идеологиях различного уровня несомненно. Именно вера на ранних этапах человеческой истории узаконивала общий порядок, побуждала людей жертвовать личными интересами и даже жизнью ради социальных приоритетов. «Если идеология опирается на веру (говорят, например, о вере в социализм), то последняя, конечно, основательно отличается от религиозной веры. Для религиозно верующего его вера дана благодаря божеству, для идеологически верующего, напротив, его вера коренится только в человеке и его истории, идеологическая вера понимается поэтому как секуляризованная, профанная вера» 6, с.338].

На наш взгляд, к основным ориентациям идеологических концепций уместно будет применить терминологию Э.Фромма. В работе «Иметь или Быть» он эффективно использует диалектику понятий «обладание» и «бытие», обнаруживая здесь водораздел социокультурных ориентаций человечества вообще. Он пишет: «При существовании по принципу обладания отношение к миру выражается в стремлении сделать его объектом «владения», в стремлении превратить все и всех, в том числе и самого себя, в свою собственность» [5, с. 211]. Инкорпорирование - действительное или символическое - граничная черта обладания, когда объект поглощается, теряет себя и включается субъектом инкорпорирования в свое физическое тело. «Архаическая форма владения какой-либо вещью, которую человек съедает или выпивает, и представляет собой инкорпорирование» [5, с. 213].

Ориентация на бытие, в противоположность ориентации на обладание, означает постоянное чувство причастности к многообразию всего существующего, позволяющее обнаруживать в последнем реализацию жизненного процесса - имманентное изменение и развитие.

В зависимости от идеологических ориентаций меняется функциональная направленность веры. Вера в идеологических концепциях не требует никаких рациональных доказательств; она представлена совокупностью формулировок аксиомного плана или императивов поведения, созданных другими людьми, которые человек воспринимает в силу того, что он ощущает зависимость от других людей. «В результате человек приобретает чувство уверенности ... и как бы получает пропуск, позволяющий примкнуть к большой группе людей. Это осво- 
бождает человека от тяжелой необходимости самостоятельно мыслить и принимать решения ... Вера по принципу обладания придает уверенность; она претендует на утверждение абсолютного неопровержимого знания, которое представляется правдоподобным, так как сила тех, кто распространяет и защищает эту веру, кажется непоколебимой» $[5$, с. 229$]$.

Сложнее обстоит дело с верой по принципу бытия. Здесь, как и в первом случае, следование определенным идеям, поклонение авторитетам также может иметь место. Но только на уровне веры по принципу бытия индивид руководствуется выработанной внутренней ориентацией на возможные события внутренней и внешней жизни общества. Причем эта ориентация уже не зависит от адекватности полученных знаний; никакие новые знания не в состоянии поколебать уверенности в единственной установке индивида, которая обеспечивает ему чувство надежного основания для постижения прошлого, настоящего и будущего.

В процессе эволюции социума человек открывает, что некое знание не может быть просто «принято к сведению» (как это имеет место, например, с моралью), а требует ответа в форме определенного поступка. Этим ответом оказывается вера. Рассматриваемая в данном ракурсе вера - исчерпывающее знание предмета, взятого не в своих отдельных деталях или функциях, а как «обнаженная» сущность, отличающая себя от всего иного, включая даже собственные проявления.

Религиозная вера требует верить не в то, что возможно увидеть и вообще воспринять с помощью органов чувств, не в то, что возможно фактологически или логически доказать, а в то, что не достижимо для человеческого восприятия, чего нельзя постичь эмпирическими методами. Эта вера выступает как самодостаточное знание, не испытывающее нужды в дополнительных аргументах ни теоретикопознавательного, ни экспериментально-фактологического планов.

Следует отметить, что поскольку личный опыт индивида на протяжении веков подтверждает влияние чуждых, неподконтрольных ему сил на повседневную практическую жизнь, постольку эта область попадает в разряд сверхъестественного. В мысленной модели мира область сверхъестественного сосуществует с миром социальных и природных реальностей, а потому и воспринимается в их ряду, не нуждаясь в каких-либо эмпирических или прочих аргументах. Но если определяющую характеристику религиозной веры видеть единственно в идее сверхъестественного и ограничиться только этим, то окажется невозможным провести границу между религией и религиозно- 
стью, между религией как формой общественного сознания и религиозной идеологией. Ведь постулирование особого сверхприродного, сверхъестественного мира, вечных надындивидуальных ценностей - существенная черта всех форм культуры. Поиски вечного в преходящем, абсолютного в относительном - такова суть и главная форма духовной культуры. Кроме веры в реальное существование сверхъестественного, божественного, религия предполагает и веру в реальную возможность непосредственно или опосредованно устанавливать личный контакт с божеством, молитвами добиваться каких-то благ. Без этой второй стороны религия не может выполнять функции идеологии.

Вера человека в трансцендентный мир связана с тем, что он учитывает наличие этого мира в своих действиях, не обращаясь ни к чувственной, ни к рациональной формам его постижения. В известном смысле можно полагать, что вера ориентирует человеческую деятельность, задает смысложизненные ориентиры, т. е. выполняет идеологические функции: «религия - это тоже идеология, одна из древнейших систем взглядов, ориентирующих человека в жизни, объясняющих смысл этой жизни» [2, с. 55].

В качестве выводов данной статьи отметим следующее.

1. Вера возникает как сдерживающий фактор, препятствующий погружению человека в мир исключительно утилитарных приоритетов. Социальный прогресс основывается не только на позитивном знании, но и на вере. Поэтому наличие черт мифологической и религиозной веры в идеологиях различного уровня несомненно, т.к. именно вера на всех этапах социальной эволюции узаконивает общий порядок, побуждает людей поступаться личными интересами ради социальных приоритетов.

2. Функциональная направленность веры изменяется в зависимости от идеологических ориентаций. Но во всех случаях, будучи включенной в идеологические концепции, вера выступает в форме императивов аксиомного плана или чистых предписаний должного поведения, не требующих рационального обоснования. Поэтому наращивание знаний не может оказывать существенного воздействия на установки личности, руководствующейся основоположениями веры. Последние обеспечивают личности надежные ориентиры в мире добра и зла, вечного и преходящего, существенного и несущественного. При этом нацеленность на поступок превращает верующего человека в человека действия, постоянно утверждающего всем своим поведением неслучайность собственного бытия и социально-космическую значимость по- 
ступков.

3. Религия, выступая в функции идеологии, расширяет коммуникативные возможности человека через постулирование бытия сверхприродного и высших надындивидуальных ценностей. Известное отстранение (и тем самым - защита) верующих от происходящих социальных изменений позволяет направлять физические и духовные усилия человека на постижение смысла происходящего не только в мире, но и в душе человека. Но без религиозной интерпретации нерелигиозных отношений между людьми религия не может отправлять свою идеологическую функцию и утрачивает свой престиж.

\section{1 Литература}

[1] Бергер П. Капиталистическая революция /50 тезисов о процветании, равенстве и свободе.-М.: Прогресс-Универс, 1994.

[2] Карпинская Р. И все-таки идеология // Знание-сила. - 1991. № 4. - C. 54-58.

[3] Ортега-и-Гассет X. Идеи и верования // Ортега-и-Гассет Х. Эстетика. Философия культуры. - М.: Искусство, 1991. - С. 296-308.

[4] Рассел Б. Человеческое познание: Его сфера и границы. - К.: Ника-Центр, 1997.

[5] Фромм Э. Психоанализ и религия; Искусство любить; Иметь или Быть? - К.: Ника-Центр, 1998.

[6] Хюбнер К. Истина мифа. - М.: Республика, 1996.

[7] Яковлев А.И. Религиозное сознание.-М.: Компания Спутник, 2004. 